${ }^{1}$ UTP University of Science and Technology in Bydgoszcz, Faculty of Agriculture and Biotechnology, Department of Soil Science and Soil Protection ul. Bernardyńska 6, 85-029 Bydgoszcz, Poland

${ }^{2}$ University of Warmia and Mazury in Olsztyn, Faculty of Environmental Management and Agriculture, Department of Soil Science and Land Reclamation Plac Eódzki 3, 10-727 Olsztyn, Poland

\title{
Mineral matter composition of drained floodplain soils in north-eastern Poland
}

\begin{abstract}
Soils in two river valleys (Rozoga and Omulew) in north-eastern Poland were investigated. The valleys are located on a sandy outwash plain formed during the Vistulian (Weichelian) Glaciation. The soils are drained, used as meadows and classified as Fluvic Umbric Gleysol, Fluvic Mollic Gleysol, and Eutric Fluvic Histic Gleysol (IUSS Working Group WRB 2015). The aim of the study was to identify the composition of mineral matter and to determine the types of clay minerals and intermediate stages of clay minerals by means of the X-ray diffraction (XRD). The studied floodplain soils are rich in organic matter and contain considerable mineral alluvial admixtures. The content of clay fraction $(<2.0 \mu \mathrm{m})$ is low $(0.02-5.61 \%$ of total mineral matter). Higher content of clay fraction was noted in soils with elevated content of organic matter, which can be evidence of simultaneous accumulation of both components. In deeper depressions occurring in river valleys (oxbow lakes), a specific deposit termed silty telmatic mud (16-24\% TOC, $50-75 \%$ silt, $3.1-5.6 \%$ clay fraction content) was accumulated. On the other hand, in shallow depressions, a muddy deposit was accumulated (5.7-7.7\% TOC, sandy texture). The main identified clay minerals were smectite, vermiculite, illite and kaolinite as well as variety of mixed-layer clays. Alluvial clay admixture in studied soil formations showed mineralogical similarity to typical floodplain mineral soils (Fluvisols). Mineral fraction of studied soils is mostly of allochthonous origin.
\end{abstract}

Keywords: river valleys, silty telmatic mud, mud soils, clay minerals, mursh forming process

\section{INTRODUCTION}

Soils rich in organic matter frequently occur in river valleys. In some river valley sections, in small depressions located on the floodplains, simultaneous accumulation of well-decomposed organic matter (of autogenous origin as well as transported by river waters) and fine-grained mineral particles takes place (Kalisz and Łachacz 2008; Devesa-Rey and Barral 2012; Gonzáles et al. 2014; Wójcicki 2015; GrafRosenfellner et al. 2016). Organic deposits accumulating in these places resemble well-decomposed low-moor peat (fen peat) and are termed "muds" (Okruszko 1969). These soil formations are characteristic for river valleys with a natural or semi-natural hydrological regime, i.e. with regular floods by waters relatively well saturated with oxygen (Okruszko 1969). Due to the substantial admixture of mineral particles, organic matter content in muds amounts to $20-60 \%$, and is lower than in typical peats. Like all organic materials, they undergo the process of organic matter transformation after drainage known as the mursh-forming process (Okruszko and Ilnicki 2003). This process was described in the literature under various terms, e.g. peat ripening (Pons 1960), muckforming process or moorsh-forming process ( Kachacz and Kalisz 2016). In this paper, the authors use the term „mursh”, as the qualifier „Murshic” is used in the WRB system (IUSS Working Group WRB 2015) to describe drained organic soils. During the murshforming process, intense mineralization and humification of the soil organic matter takes place (Piaścik and Lachacz 2001; Heller and Zeitz 2012; Łachacz and Kalisz 2016). Mursh formations lack remnants of plant tissues and have a granular, sometimes pulverized structure. Similar to mursh, but having less organic matter (3-20\%), are mineral-organic soil formations called mursh-like formations. These formations are divided into postmurshic (3-10\% SOM) and semimurshic (10-20\% SOM) based on soil organic matter (SOM) content as proposed by Kabała et al. (2016).

These specific organic and mineral-organic soil formations occurring on the floodplains are relatively poorly described in the literature. The elucidation of their origin on the basis of the reconstruction of vegetation based on plant macrofossils was carried out by Gałka and Kalisz (2008). The studied deposits 
were accumulated in a water-swamp environment where aquatic and rush plant species were present. Floodplain soils act as a sink of chemical elements carried by river waters, and often accumulate substantial contents of nutrients (Kalembasa et al. 2009; Kalisz and Łachacz 2009; Tsheboeng et al. 2014; Sowiński et al. 2016).

Changes in organic matter of floodplain soils under influence of drainage were described by Kalisz et al. (2010). However, the mineral composition of clay fraction $(\varnothing<2.0 \mu \mathrm{m})$ in organic soils has barely been studied and needs considerable attention as clay fraction stabilizes organic matter after drainage of these soils (Heller and Zeitz 2012; Graf-Rosenfellner et al. 2016). The investigations of mineral composition of floodplain soils were focused mainly on mineral soils (Dąbkowska-Naskręt and Dlugosz 1996). The composition of soil clay fraction carries information on degrees of weathering and is essential for interpreting soil genesis and soil properties.

Knowledge of the composition of river valley soil mineral matter, including types of clay minerals, will add value to the soil science by answering the following questions:

- what is the origin (alimentation zone) of the mineral part of these soils,

- what is the intensity and extent of the geomorphological processes in the catchment,

- which processes occur in soils after the sedimentation of soil material,

- what are the directions of evolution of drained soils rich in organic matter.

Higher amounts of clay fraction will stabilize soil organic matter and will protect it against mineralization that leads to the formation of mollic horizons and evolution towards black earths (Mollic Gleysols). On the contrary, low amount of clay fraction with intensive long-term drainage leads to the oxidation of organic matter and evolution towards Arenosols (Kalisz and Łachacz 2008; Łabaz and Kabala 2016).

The aim of the study was to identify mineral composition of floodplain soils and determine the types of clay minerals and intermediate stages of clay minerals by means of X-ray diffraction (XRD) method. An important aspect of the paper was the description of mud soils in terms of composition and origin of soil mineral components.

\section{STUDY AREA}

The studied area is located in north-eastern Poland. According to physico-geographical division of Poland, it is situated in the mesoregion of Kurpie Plain formed by fluvioglacial sands of the Vistulian
(Weichelian) Glaciation (Kondracki 2002). It is a part of the largest outwash plain in Poland with an area of approximately $5,400 \mathrm{~km}^{2}$. The Quaternary deposits have thickness of 100-150 m, and the Miocen sands lay underneath. In the investigated area, two studied rivers - Rozoga and Omulew flow in the previous tracks of glaciofluvial waters. The northern part of the outwash plain is surrounded by the moraines of the Leszno phase of the Vistulian Glaciation. The surface of the plain is situated $100 \mathrm{~m}$ above sea level in the south and $150 \mathrm{~m}$ above sea level in the north (Kondracki 2002). The investigated rivers, Rozoga and Omulew, flow into Narew river which is right side tributary of Vistula (Wisła) river.

The river Rozoga is $82 \mathrm{~km}$ long. The floodplain was shaped in the early Holocene by medium and fine sands with substantial admixture of organic matter and frequently bog iron ore (Bałuk 1993; Kondracki 1972, 2002; Listkowska 1999a, 1999b). The accumulation of organic materials began in the Atlantic and Subboreal periods. The river was regulated at the very beginning of $20^{\text {th }}$ century and its valley was drained.

The river Omulew is $114 \mathrm{~km}$ long and has numerous meanders and oxbow lakes, which affect the water regime and form the river's natural character. The floodplain was built up by medium and fine sands with admixture of plant remnants and humus (Listkowska 1999b).

\section{MATERIALS AND METHODS}

For this research, soils in two river valleys (Rozoga and Omulew) in north-eastern Poland were selected. In the 1930s and 1950s the rivers were regulated (channelized) and their valleys were drained in order to obtain more land for agricultural use. Soil samples were taken from three sites: Walery Łęg and Kapuściska sites in Rozoga river valley and Gleba site in Omulew river valley. The location of the sites is shown in Figure 1. The soils that developed on the floodplains are drained and used as meadows. The detailed description of soil profiles is presented in previous paper (Kalisz and Łachacz 2008). Five soil profiles were examined. Clay minerals were separated from selected samples numbered from 1 to 7 (Table 1).

Particle size distribution was analysed by means of the pipette method using apparatus produced by Eijkelkamp Agrisearch Equipment (ISO 13317-2: 2001). This method is based on sedimentation of soil particles in water. Solutions of $4 \%\left(\mathrm{NaPO}_{3}\right)_{6}$ and $1 \%$ $\mathrm{Na}_{2} \mathrm{CO}_{3}$ were used as a chemical dispersion agents of soil particles and then soil suspension was stirred. In the pipette method, soil material of $\varnothing<2.0 \mathrm{~mm}$ was 


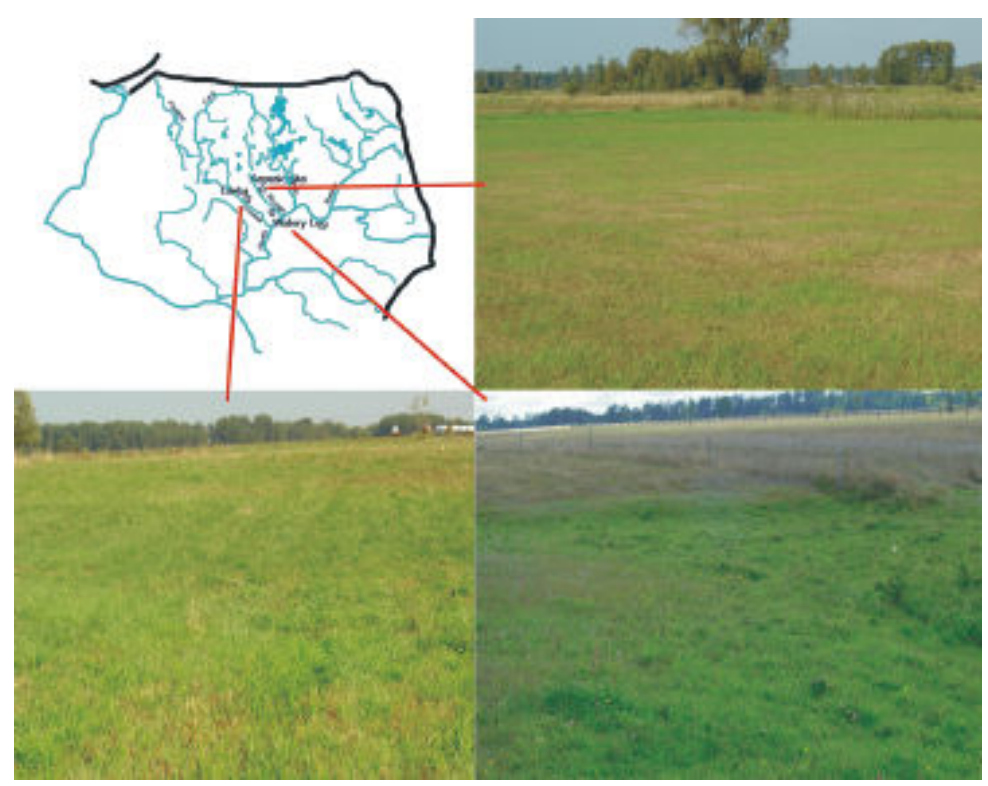

FIGURE 1. Location of the studied sites

TABLE 1. Soil morphology and soil classification

\begin{tabular}{|c|c|c|c|c|c|c|}
\hline \multirow{2}{*}{$\begin{array}{l}\text { Soil } \\
\text { horizon }\end{array}$} & \multirow{2}{*}{$\begin{array}{l}\text { Depth } \\
(\mathrm{cm})\end{array}$} & \multirow{2}{*}{$\begin{array}{l}\text { Sample } \\
\text { No. }{ }^{1}\end{array}$} & \multirow{2}{*}{$\begin{array}{l}\text { LOI } \\
(\%)\end{array}$} & \multicolumn{2}{|l|}{ Colour } & \multirow[t]{2}{*}{ Soil formation (radiocarbon age) ${ }^{2}$} \\
\hline & & & & dry & moist & \\
\hline \multicolumn{7}{|c|}{$\begin{array}{l}\text { Profile 1. Walery Łeg site in Rozoga river valley - muddy soil (gleba mułowata) })^{3} \text { or semimurshic soil (gleba murszowata) } \\
\text { Fluvic Umbric Gleysol (Arenic, Drainic, Humic, Limnic) }\end{array}$} \\
\hline $\mathrm{Au}$ & $0-15$ & 1 & 13.97 & 10YR3.5/2 & 10YR1.7/1 & semimurshic (muddy) \\
\hline $\mathrm{Au} 2$ & $15-35$ & 2 & 10.75 & $10 \mathrm{YR} 3 / 2$ & 10YR1.7/1 & semimurshic (muddy) $(890 \pm 30 \mathrm{BP})$ \\
\hline $\mathrm{Lc}$ & $35-50$ & - & 39.23 & $10 \mathrm{YR} 2 / 3$ & 10YR1.7/1 & telmatic mud \\
\hline $\mathrm{Cg}$ & $50-150$ & - & 0.48 & $10 \mathrm{YR} 7 / 4$ & $10 \mathrm{YR} 4 / 3$ & alluvial loose sand \\
\hline
\end{tabular}

Profile 2. Walery Łeg site in Rozoga river valley - muddy soil (gleba mułowata) ${ }^{3}$ or typical postmurshic soil (gleba murszasta typowa) ${ }^{4}$ Eutric Fluvic Mollic Gleysol (Arenic, Drainic, Humic, Limnic) $)^{5}$

\begin{tabular}{lccrlll}
\hline $\mathrm{Au}$ & $0-20$ & - & 8.93 & $10 \mathrm{YR} 5 / 3$ & $10 \mathrm{YR} 3 / 3$ & postmurshic (muddy) \\
\hline $\mathrm{Au} 2$ & $20-35$ & 3 & 19.39 & $7.5 \mathrm{YR} 3 / 2$ & $7.5 \mathrm{YR} 1.7 / 1$ & muddy \\
\hline $\mathrm{Cg}$ & $35-150$ & - & 0.47 & $10 \mathrm{YR} 7 / 4$ & $10 \mathrm{YR} 4 / 3$ & alluvial loose sand
\end{tabular}

Profile 3. Kapuś ciska site in Rozoga river valley - mud gleysol (gleba mułowo-glejowa) ${ }^{4}$

Eutric Fluvic Mollic Gleysol (Abruptic, Endoarenic, Episiltic, Drainic, Hyperhumic, Limnic) ${ }^{5}$

\begin{tabular}{lllrlll}
\hline (M)Lc & $0-18$ & 4 & 41.80 & $10 \mathrm{YR} 2.5 / 3$ & $10 \mathrm{YR} 2 / 2$ & murshic (mud) \\
\hline $\mathrm{Lc}$ & $18-33$ & 5 & 22.38 & $10 \mathrm{YR} 4 / 2$ & $10 \mathrm{YR} 2 / 2$ & telmatic mud $(2260 \pm 35 \mathrm{BP})$ \\
\hline $2 \mathrm{Cg}$ & $33-70$ & - & 1.75 & $10 \mathrm{YR} 6 / 3$ & $10 \mathrm{YR} 3 / 4$ & alluvial loose sand \\
\hline $\mathrm{G}$ & $70-150$ & - & 0.21 & $2.5 \mathrm{Y} 7 / 4$ & $2.5 \mathrm{Y} 5 / 4$ & alluvial loose sand \\
\hline
\end{tabular}

Profile 4. Gleba site in Omulew river valley - mud gleysol (gleba mułowo-glejowa) ${ }^{4}$

Eutric Fluvic Histic Gleysol (Abruptic, Endoarenic, Episiltic, Drainic, Limnic) ${ }^{5}$

\begin{tabular}{lllrlll}
\hline (M)Lc & $0-25$ & 6 & 51.52 & 10YR2.5/2 & 10YR2/1 & murshic (mud) \\
\hline $\mathrm{Lc}$ & $25-39$ & - & 24.30 & 10YR3/1 & 10YR1.7/1 & telmatic mud \\
\hline $\mathrm{Cg}$ & $39-70$ & - & 0.38 & 10YR6.5/4 & 10YR4/4 & alluvial loose sand \\
\hline $\mathrm{G}$ & $70-150$ & - & 0.16 & $2.5 \mathrm{Y} 6.5 / 2$ & $2.5 \mathrm{Y} 4 / 3$ & alluvial loose sand
\end{tabular}

Profile 5. Gleba site in Omulew river valley - muddy soil (gleba mułowata ${ }^{3}$ or typical postmurshic soil (gleba murszowata) ${ }^{4}$ Fluvic Umbric Gleysol (Abruptic, Epiarenic, Episiltic, Drainic, Limnic) ${ }^{5}$

\begin{tabular}{lclrlll}
\hline $\mathrm{Au}$ & $0-16$ & 7 & 10.75 & $10 \mathrm{YR} 3 / 3$ & $10 \mathrm{YR} 2 / 2$ & semimurshic (muddy) $(900 \pm 30 \mathrm{BP})$ \\
\hline $\mathrm{2C}$ & $16-60$ & - & 1.00 & $10 \mathrm{YR} 6.5 / 4$ & $10 \mathrm{YR} 4 / 4$ & alluvial loose sand \\
\hline $\mathrm{Lc}$ & $60-110$ & - & 26.25 & $10 \mathrm{YR} 3 / 1$ & $7.5 \mathrm{YR} 1.7 / 1$ & telmatic mud \\
\hline $\mathrm{Gc}$ & $110-150$ & - & 0.22 & $2.5 \mathrm{Y} 6.5 / 2$ & $2.5 \mathrm{Y} 4 / 3$ & alluvial loose sand \\
\hline
\end{tabular}

${ }^{1}$ number of soil sample from which clay minerals were separated (used in table 2 and 3 and on figures $2-8$ ); ${ }^{2}$ the lowest sub-layers $1 \mathrm{~cm}$ thick were analysed, ${ }^{3}$ not included in Polish Soil Classification (2011), ${ }^{4}$ Polish Soil Classification (2011), ${ }^{5}$ IUSS Working Group WRB (2015). 
used after sample pre-treatment, i.e. organic matter removal by oxidation with $30 \% \mathrm{H}_{2} \mathrm{O}_{2}$ and removal of calcium carbonates by $20 \% \mathrm{HCl}$ solution. Sandy fractions were determined by wet-sieving. The percentage of fractions of $ø 2000-50 \mu \mathrm{m}$ (sand), $50-2 \mu \mathrm{m}$ (silt) and $<2 \mu \mathrm{m}$ (clay) enabled to classify soils according to USDA (United States Department of Agriculture) system (Soil Survey Division Staff 1993) and according to Soil Science Society of Poland 2008 (PTG 2009).

The amounts of biogenic and terrigenic silica were analysed according to Tobolski (2000). The raw ash obtained after dry ashing of soil samples at $550^{\circ} \mathrm{C}$ was treated with hydrochloric acid (concentration $10 \%$ ), the solution was then filtered and dry ashed at $550^{\circ} \mathrm{C}$. Clean ash which contains biogenic and terrigenic silica was obtained. After applying potassium hydroxide (concentration 10\%) on clean ash, biogenic silica was measured (terrigenic silica does not react with potassium hydroxide).

Total organic carbon (TOC) content was measured with a spectrophotometer after oxidation with potassium dichromate (ISO 14235: 1998). Total nitrogen (TN) was determined by means of Kjeldahl method, $\mathrm{pH}$ of the soil-to-solution ratio of 1:2.5 using $1 \mathrm{M} \mathrm{KCl}$ and $\mathrm{H}_{2} \mathrm{O}$ as the suspension medium was determined potentiometrically (van Reeuwijk 2002). Soil color was determined in air-dry and moist samples according to Munsell Soil Color Charts (Oyama and Takehara 1992). Additionally the beginning of sedimentation of studied soil formations was estimated with ${ }^{14} \mathrm{C}$ radiocarbon dating at Poznań Radiocarbon Laboratory, Poland.

For mineralogical analysis, soil samples were sieved through $1.0 \mathrm{~mm}$ mesh and prepared according to the Jackson's procedure (Cieśla 1976), in which unwanted components (carbonates, organic matter and free oxides) were removed. The mineralogical composition of clay was assessed by XRD method using HZG4 (Carl Zeiss) instrument. Samples of clay fraction were saturated with $\mathrm{Mg}^{2+}$ ions, then solvated with ethylene glycol $\left(\mathrm{Mg}^{2+}+\mathrm{GE}\right), \mathrm{K}^{+}$ions and the samples were heated to $300^{\circ} \mathrm{C}$ and $550^{\circ} \mathrm{C}\left(\mathrm{K}^{+}\right.$specimens $)$.

The soils were classified according to the Polish Soils Classification (PSC 2011) and WRB classification system (IUSS Working Group WRB 2015).

\section{RESULTS}

The soil profiles 1, 2 and 5 were described as muddy soils (Table 1), which are not included in the PSC (2011). They were classified as Fluvic Umbric Gleysols (soil profile 1), Fluvic Mollic Gleysols (soil profile 2), Fluvic Umbric Gleysols (soil profile 5) according to WRB system (IUSS Working Group WRB 2015). The soil profiles 3 and 4 were classified as mud gleysols (PSC 2011) and as Eutric Fluvic Mollic Gleysols (soil profile 3), Eutric Fluvic Histic Gleysols (IUSS Working Group WRB 2015).

The investigated soils contain $107.5-515.2 \mathrm{~g} \mathrm{~kg}^{-1}$ of organic matter and $43.8-240.3 \mathrm{~g} \mathrm{~kg}^{-1}$ of organic carbon. The soil $\mathrm{C} / \mathrm{N}$ ratio in Rozoga river valley (Walery Łęg and Kapuściska) amounted to approximately 10-11, irrespective of the depth in the soil profile. However, the soil $\mathrm{C} / \mathrm{N}$ ratio in Omulew river valley amounted from 8.8 to 12.0 (Table 2). The accumulation of surface organic deposit (mud) in Rozoga valley started $2260 \pm 35{ }^{14} \mathrm{C}$ years BP (Kapuściska site, soil profile No. 3), and mineral-organic deposit (muddy formation) started $890 \pm 30{ }^{14} \mathrm{C}$ years

TABLE 2. Basic properties of the studied soils

\begin{tabular}{|c|c|c|c|c|c|c|c|c|c|c|c|}
\hline \multirow[t]{2}{*}{$\begin{array}{l}\text { Sample } \\
\text { No. }\end{array}$} & \multirow[t]{2}{*}{$\begin{array}{l}\text { Depth } \\
\text { (cm) }\end{array}$} & \multirow{2}{*}{$\begin{array}{l}\text { TOC } \\
\mathrm{g} \cdot \mathrm{kg}^{-1}\end{array}$} & \multirow[t]{2}{*}{$\mathrm{TN}$} & \multirow[t]{2}{*}{$\mathrm{C} / \mathrm{N}$} & \multirow{2}{*}{$\begin{array}{l}\mathrm{pH} \\
\mathrm{KCl}\end{array}$} & \multirow{2}{*}{$\begin{array}{l}\mathrm{pH} \\
\mathrm{H}_{2} \mathrm{O}\end{array}$} & \multicolumn{3}{|c|}{$\begin{array}{l}\text { Percentage of mineral } \\
\text { fraction }(\mu \mathrm{m})\end{array}$} & \multirow{2}{*}{$\begin{array}{l}\text { Texture } \\
\text { class } \\
\text {-(PTG } \\
2009)\end{array}$} & \multirow[t]{2}{*}{$\begin{array}{l}\text { Texture class } \\
\text { (USDA) }\end{array}$} \\
\hline & & & & & & & $2000-50$ & $50-2$ & $<2$ & & \\
\hline \multicolumn{12}{|c|}{ Walery Łeg site in Rozoga river valley } \\
\hline 1 & $0-15$ & 77.4 & 7.1 & 10.9 & 5.2 & 6.0 & 83.8 & 14.6 & 1.6 & pg & Loamy sand \\
\hline 2 & $15-35$ & 57.9 & 5.3 & 10.9 & 5.0 & 5.7 & 95.2 & 4.6 & 0.2 & $\mathrm{pl}$ & Sand \\
\hline 3 & $20-35$ & 72.1 & 7.2 & 10.0 & 6.1 & 6.9 & 92.9 & 7.0 & 0.0 & $\mathrm{pl}$ & Sand \\
\hline \multicolumn{12}{|c|}{ Kapuściska site in Rozoga river valley } \\
\hline 4 & $0-18$ & 164.4 & 15.6 & 10.5 & 5.0 & 5.9 & 43.9 & 51.6 & 4.5 & pyg & Silt loam \\
\hline 5 & $18-33$ & 90.3 & 8.4 & 10.7 & 5.3 & 6.3 & 41.1 & 55.8 & 3.1 & pyg & Silt loam \\
\hline \multicolumn{12}{|c|}{ Gleba site in Omulew river valley } \\
\hline 6 & $0-25$ & 240.3 & 20.0 & 12.0 & 5.3 & 6.0 & 35.8 & 58.5 & 5.6 & pyg & Silt loam \\
\hline 7 & $0-16$ & 43.8 & 5.0 & 8.8 & 5.9 & 7.0 & 20.3 & 75.0 & 4.6 & pyg & Silt loam \\
\hline
\end{tabular}

pg - loamy sand, $\mathrm{pl}$ - sand, pyg - silt loam. 
BP (Walery Łęg site, soil profile No. 1). The age of surface deposit (muddy formation) in Omulew river valley (soil profile No. 5) is $900 \pm 30{ }^{14} \mathrm{C}$ years BP.

The research showed that the analysed soil samples differ in the content of sand, silt and clay fractions and have sandy, loamy sandy and silty loamy texture (Table 2). The highest content of clay fraction was found in soils at Kapuścicka and Gleba sites, which also have enhanced content of organic carbon.

The investigated soil formations contain from 48 to $89 \%$ of raw ash (Table 3 ). The main component of raw ash is quartz particles of sand and silt size. The further constituents of raw ash are compounds soluble in hydrochloric acid, mostly iron oxides. It should be noted that their content is enhanced in soil formations rich in organic matter, i.e. mursh formations at Kapuściska and Gleba sites (soil profiles No. 3 and 4). When clean ash is considered, it should be noted that the studied soil formations contain more quartz (terrigenic silica) than biogenic silica. The total content of biogenic silica is below $2 \%$ of clean ash. Its higher content (1.69-1.77\% of clean ash) was found in soils accumulated in a shallow lake occurring in Rozoga river valley (Kapuściska site, soil profile No. 3).

Clay fraction $(<0.002 \mathrm{~mm})$ of analyzed soils contains clay minerals that occur in both discrete and mixed-layer forms. Smectite was found in all samples based on occurrence of the broad $1.4 \mathrm{~nm}$ peak $\left(\mathrm{Mg}^{2+}\right.$ saturated specimens), which moved to 1.68-1.70 $\mathrm{nm}$ after solvation with ethylene glycol $\left(\mathrm{Mg}^{2+}+\mathrm{GE}\right)$ (Fig. 2-8). Furthermore, vermiculite (a peak $1.4 \mathrm{~nm}$ after EG treatment) occurs in some samples (Fig. 4 and 5). The studied clay fractions may also contain

TABLE 3. Ash composition of the studied soils

\begin{tabular}{|c|c|c|c|c|c|c|}
\hline \multirow[t]{2}{*}{$\begin{array}{l}\text { Sample } \\
\text { No. }\end{array}$} & Depth & $\begin{array}{l}\text { Raw } \\
\text { ash }\end{array}$ & $\begin{array}{l}\text { Clean } \\
\text { ash }\end{array}$ & $\begin{array}{l}\text { Compon- } \\
\text { ents easily } \\
\text { soluble in } \\
\text { hydroch- } \\
\text { oric acid }\end{array}$ & $\begin{array}{l}\text { Terrigenic } \\
\text { silica }\end{array}$ & $\begin{array}{l}\text { Biogenic } \\
\text { silica }\end{array}$ \\
\hline & $(\mathrm{cm})$ & \multicolumn{2}{|c|}{$(\% \mathrm{DM})$} & & \multicolumn{2}{|l|}{$(\%)^{*}$} \\
\hline \multicolumn{7}{|c|}{ Walery Łęg site in Rozoga river valley } \\
\hline 1 & $0-15$ & 86.03 & 83.31 & 2.72 & 98.75 & 1.25 \\
\hline 2 & $15-35$ & 89.25 & 87.43 & 1.82 & 99.23 & 0.77 \\
\hline 3 & $20-35$ & 80.61 & 76.17 & 4.44 & 99.14 & 0.86 \\
\hline \multicolumn{7}{|c|}{ Kapuś ciska site in Rozoga river valley } \\
\hline 4 & $0-18$ & 58.20 & 50.14 & 8.06 & 98.31 & 1.69 \\
\hline 5 & $18-33$ & 77.62 & 72.14 & 5.48 & 98.23 & 1.77 \\
\hline \multicolumn{7}{|c|}{ Gleba site in Omulew river valley } \\
\hline 6 & $0-25$ & 48.48 & 42.20 & 6.28 & 98.95 & 1.05 \\
\hline 7 & $0-16$ & 89.25 & 86.35 & 2.90 & 99.37 & 0.63 \\
\hline
\end{tabular}

$\mathrm{DM}$ - dry matter; * in relation to clean ash. swelling chlorite and/or chlorite-vermiculite. Moreover, illite (the 001 peak at $\sim 1.0 \mathrm{~nm}$ which does not change its position neither after GE treatment) and kaolinite (the peaks 0.720 and $0.356 \mathrm{~nm}$ which does not shift after GE treatment) was identified. Additionally, quartz (peaks $0.426 \mathrm{~nm}$ and $0.334 \mathrm{~nm}$ ), amphibole (peak $0.85 \mathrm{~nm}$ ) and feldspars (peaks $0.330-0.315$ $\mathrm{nm}$ and $0.430-0.410 \mathrm{~nm}$ ) were present in the studied clay fraction.

Certain differences in the type of clay minerals occurring in soils were found. The mineral alluvial admixture of studied soils at Walery Łęg in Rozoga river valley had loamy sandy and sandy texture (Table 2) and contained very low concentration of clay. The mineralogical composition of fraction $<2.0$ $\mu \mathrm{m}$ showed that predominant swelling clay mineral was smectite as expressed by the peak of $1.700 \mathrm{~nm}$ of magnesium-ethylene glycol specimen and 1.280$1.200 \mathrm{~nm}$ of $\mathrm{K}^{+}$specimen (Fig. 2-4). The analyzed clay fraction may also contain some vermiculite or kaolinite minerals shown by the peaks of $1.100,0.356$ $\mathrm{nm}$ in $\mathrm{K}^{+}$specimen and illite minerals expressed by the peaks of $1.000,0.500,0.334 \mathrm{~nm}$ also in $\mathrm{K}^{+}$specimen.

On the floodplain of Rozoga river at Kapuściska site, mursh contained alluvial admixture of silty loamy texture. The analysed soils contained $3-4 \%$ of clay (Table 2). In soil sample from the layer of $18-33 \mathrm{~cm}$, typical smectite minerals prevailed, which was demonstrated by the peaks of $1.680 \mathrm{~nm}$ of magnesium-ethylene glycol specimen (Fig. 5 and 6).

In Omulew river valley, studied soils contained alluvial admixture of silt loam texture. These soils contained more clay and silt than the soils at Walery and Kapuściska sites in Rozoga river valley (Table 2).

\section{DISCUSSION}

Classification of soils occurring in river valleys is difficult due to overlapping of various processes of accumulation of soil materials and their further pedogenesis. River valley habitats are heterogenous, with land depressions formed during accumulation of fluvioglacial sediments and during activity of the river, i.e. oxbow lakes (Kittel et al. 2016). The soil profiles 1 and 5 were classified as semimurshic subtype and the soil profile 2 as typical postmurshic soil (PSC 2011). However, the systematic position, emphasizing the occurring mursh-forming process, does not fully reflect the identity of soil formation and its alluvial-telmatic origin. Therefore, it is suggested to include the muddy soil sub-type in postmurshic soil type or muddy gleysols subtype in gleysols type (Roj-Rojewski 2003, 2009; Kalisz and Łachacz 2008; Mendyk et al. 2015; Glina et al. 2016). 

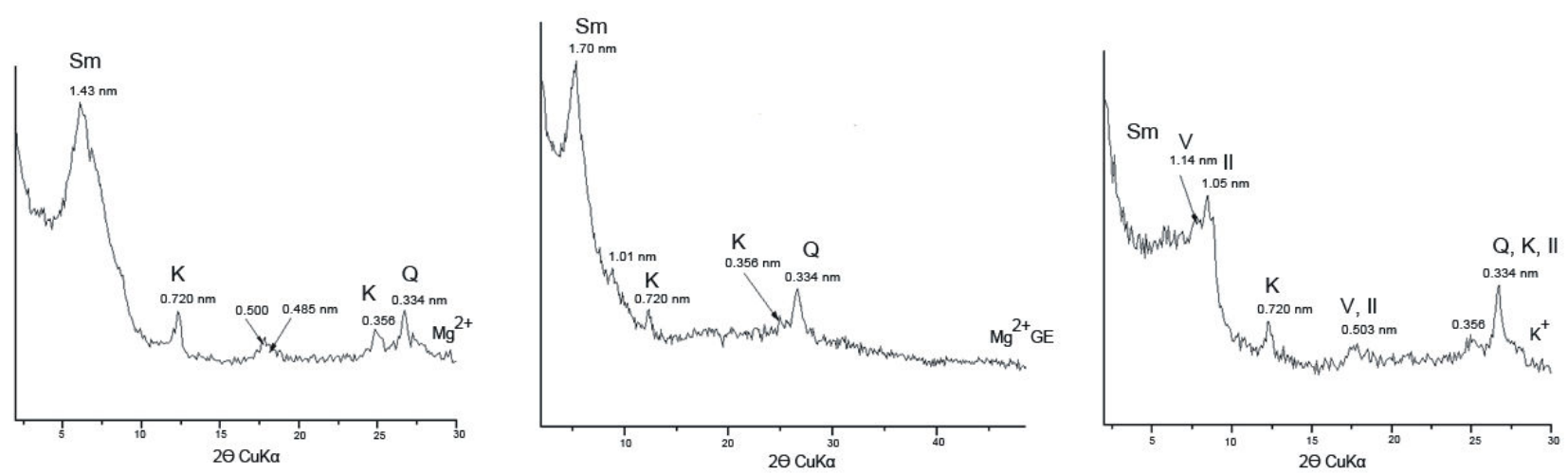

FIGURE 2. XRD patterns for clay fraction from $0-15 \mathrm{~cm}$ soil layer (sample No. 1) at Walery Łęg in Rozoga river valley. Mineral symbols: Il - illite, K - kaolinite, Q - quartz, Sm - smectite, V - vermiculite

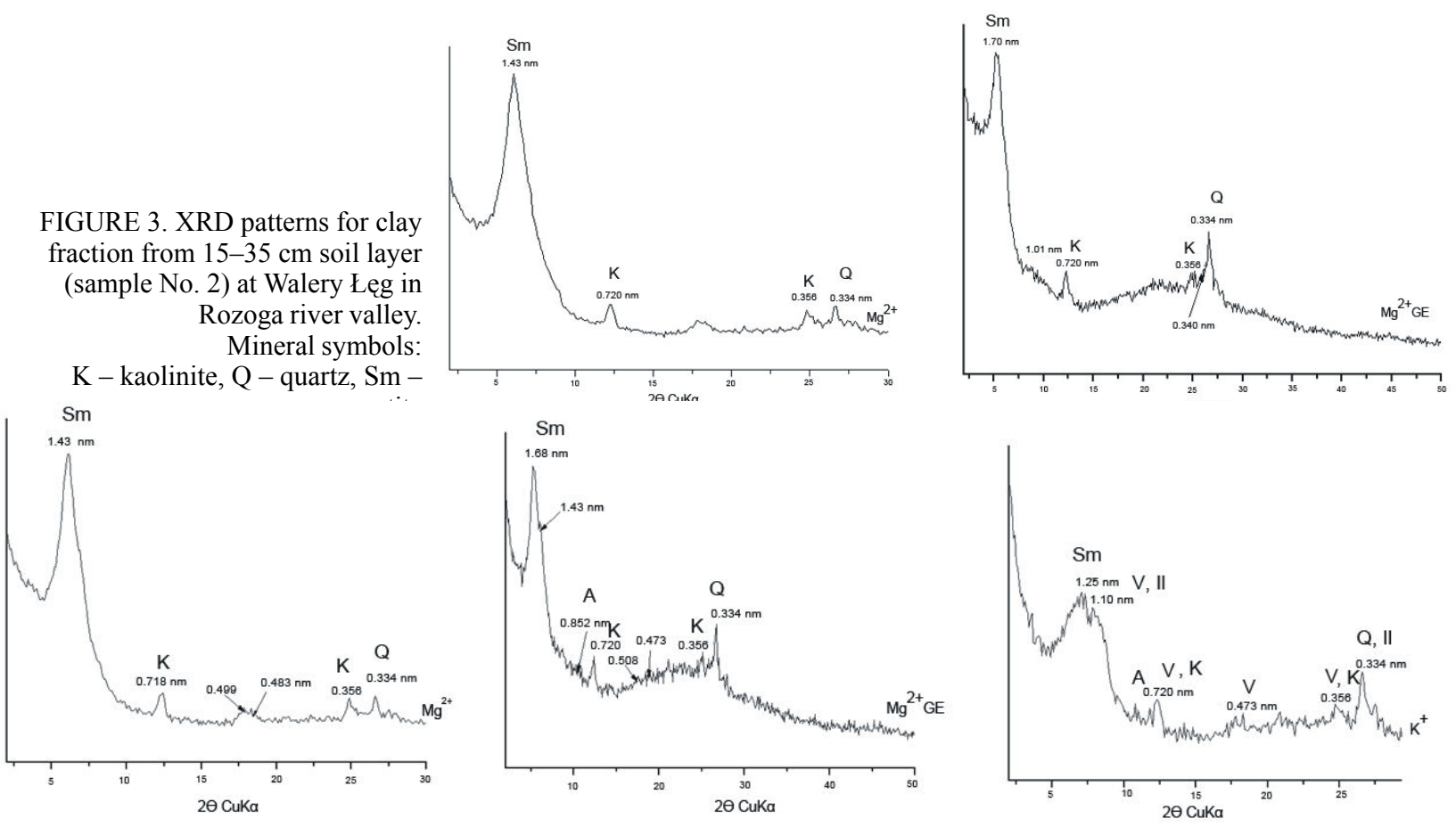

FIGURE 4. XRD patterns for clay fraction from 20-35 cm soil layer (sample No. 3) at Walery Łęg in Rozoga river valley. Mineral symbols: A - amphibolite, Il - illite, K - kaolinite, Q - quartz, Sm - smectite, V - vermiculite

Soil profiles 3 and 4 were classified as mud gleysols in the gley soil type (PSC 2011), which is consistent with the character of surface soil formation, but the information about murshing is however lost.

According to the WRB system (IUSS Working Group WRB 2015) all soils studied were included in Gleysols Reference Soil Group. The existing principal and supplementary qualifiers describe well the specificity of the soils. However, it should be noted that the WRB system includes the studied soil formations in the limnic material, accenting their lake origin. In fact it is specific soil formations termed silty telmatic mud.

In biogenic deposits, especially in those of lacustrine origin, the content of biogenic silica (opal), which is a component of so-called raw ash, is important
(Tobolski 2000). In lacustrine basins, terrigenic and biogenic sedimentation, as well as chemogenous sedimentations of amorphous and crystalline matter take place. It is generally assumed that in fluvial systems terrigenic matter is of allochthonous origin and biogenic matter is mostly of autogenic origin (e.g. Tobolski 2000). This consists of diatom and other phytolith fragments, amorphous organic matter, mollusks, ostracods (Goldman and Horne 1983; Lerman et al. 1995; Borówka 2007). The wide range of raw ash content in the investigated soils is a result of local differences in accumulation as well as further oxidation of organic matter after drainage. Considering the analysis of terrigenic and biogenic silica, it should be stated that the prevalence of terrigenic silica in mineral fraction proves that this mat- 

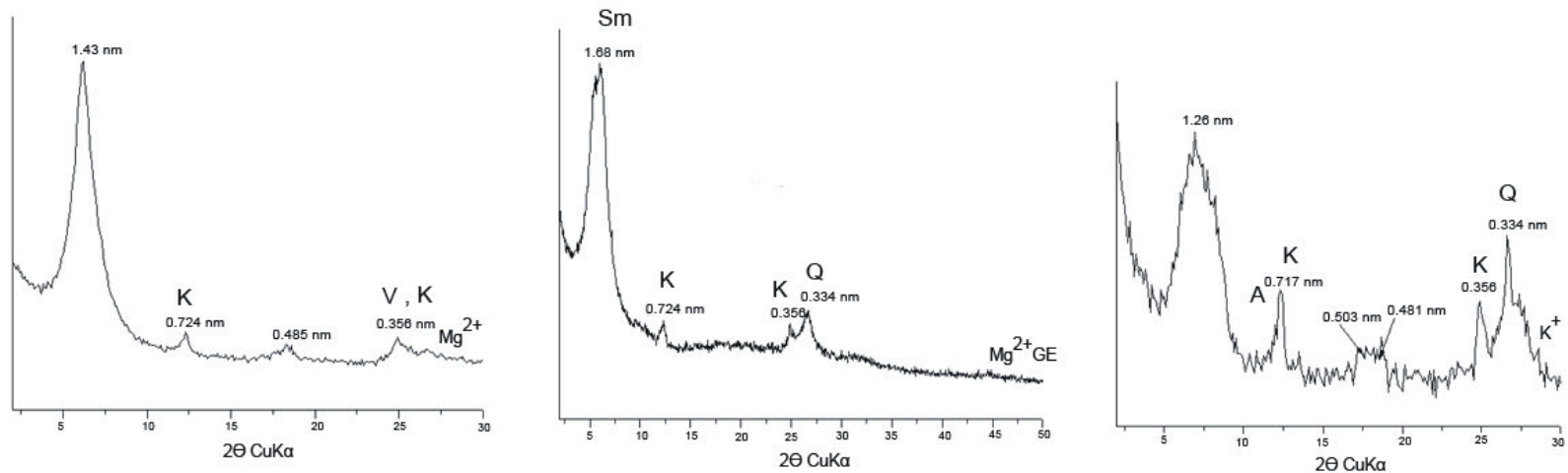

FIGURE 5. XRD patterns for clay fraction from 0-18 cm soil layer (sample No. 4) at Kapuściska in Rozoga river valley. Mineral symbols: A - amphibolite, $\mathrm{K}$ - kaolinite, Q - quartz, Sm - smectite, V - vermiculite
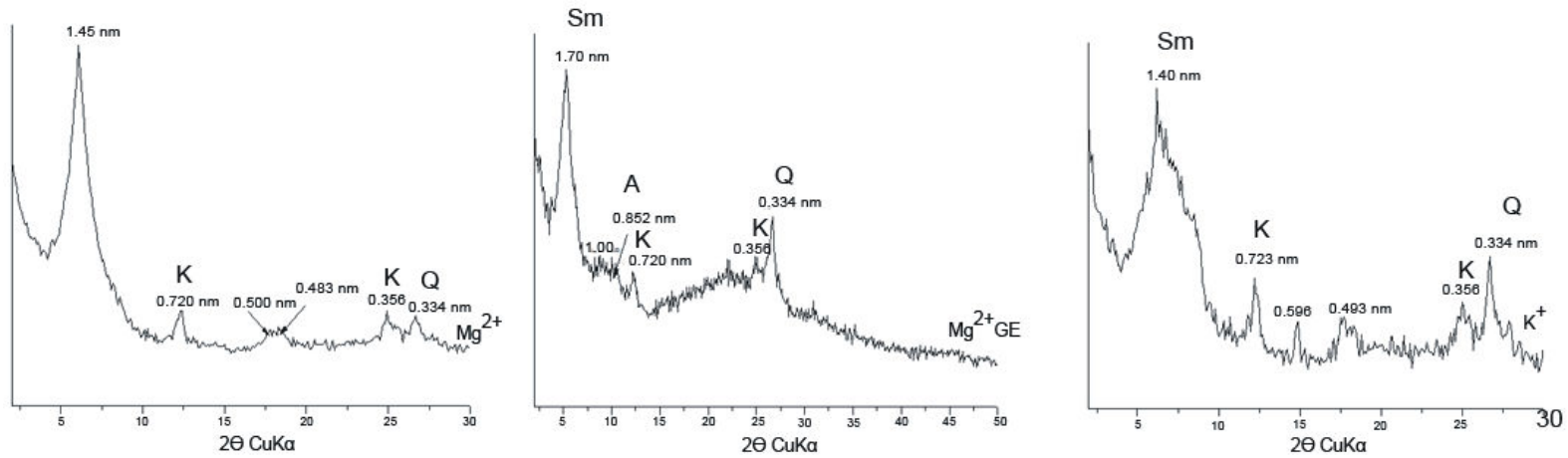

FIGURE 6. XRD patterns for clay fraction from 18-33 cm soil layer (sample No. 5) at Kapuściska in Rozoga river valley. Mineral symbols: A - amphibolite, K - kaolinite, Q - quartz, Sm - smectite
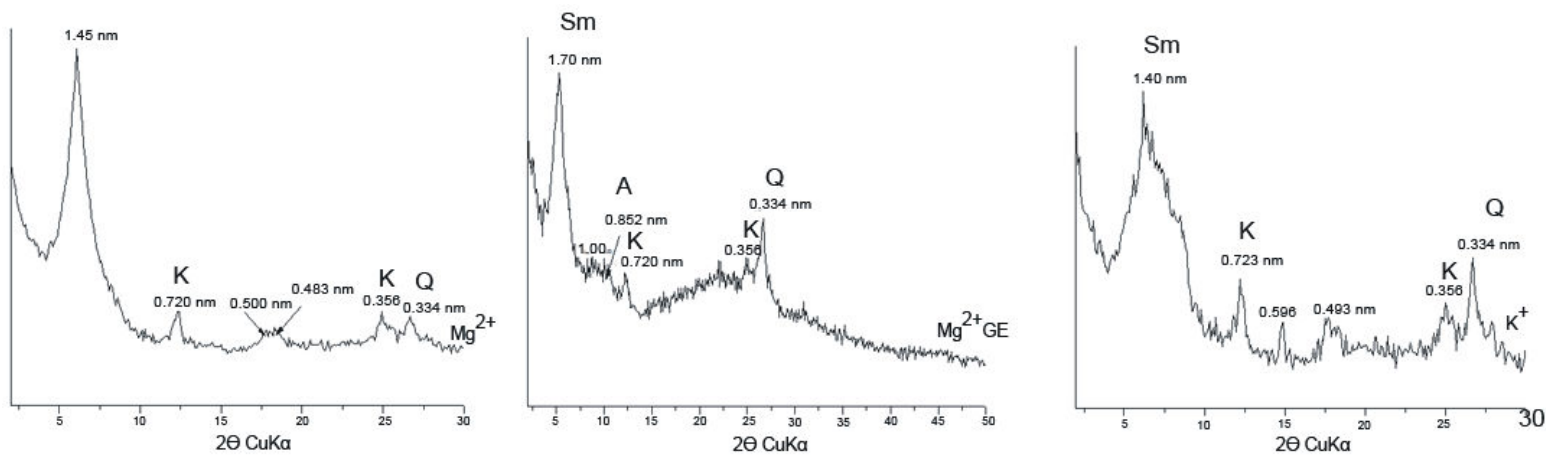

FIGURE 7. XRD patterns for clay fraction from 0-25 cm soil layer (sample No. 6) at Gleba in Omulew river valley. Mineral symbols: A - amphibolite, $\mathrm{K}$ - kaolinite, Q - quartz, Sm - smectite
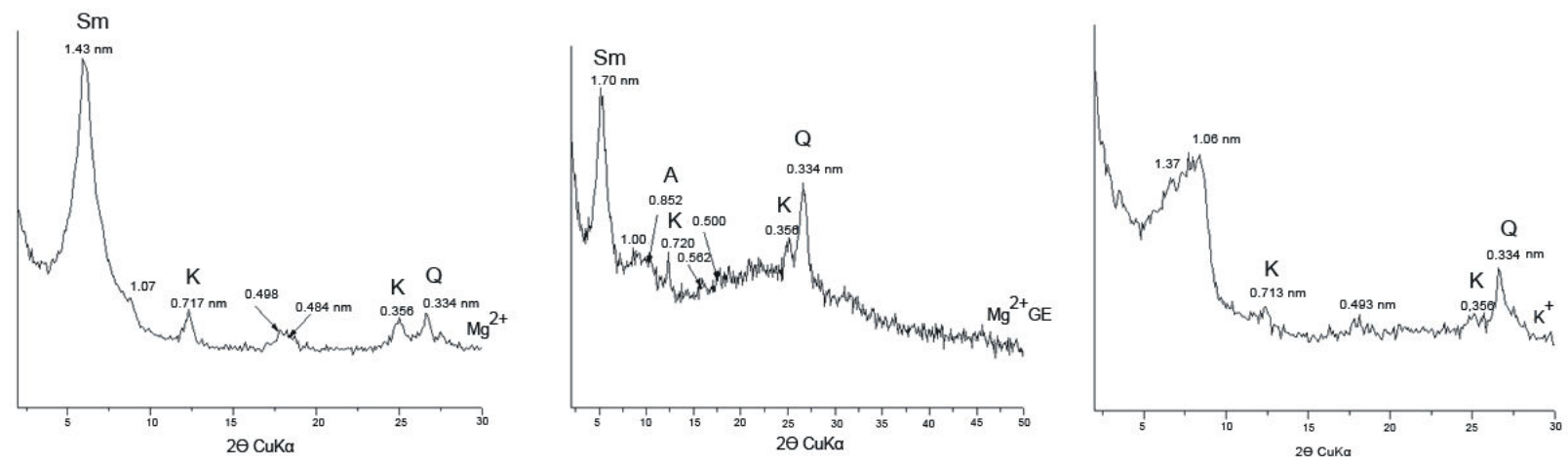

FIGURE 8. XRD patterns for clay fraction from 0-16 cm soil layer (sample No. 7) at Gleba in Omulew river valley. Mineral symbols: A - amphibolite, $\mathrm{K}$ - kaolinite, Q - quartz, Sm - smectite 
ter is of allochthonous origin. Only a small proportion of silica is of autochthonous origin (living organisms). It is assumed that biogenic silica is mostly of autogenous origin (Bengtsson and Enell 1986; Tobolski 2000; Borówka 2007). Occurrence of biogenic silica suggests that the investigated formations were accumulated under water (long-lasting floods or oxbow lakes) which enabled development of aquatic organisms, which later constitute the biogenic silica (Gałka and Kalisz 2008).

All studied soils contained low amounts of mineral fraction of $ø<2.0 \mu \mathrm{m}$. However, it should be noted that the content of clay fraction is much higher than in the surrounding soils which were formed from fluvioglacial sands and which frequently contain less than $1.0 \%$ of clay (usually less than $0.1 \%$ ) (Kalisz and Eachacz 2008). This also proves the thesis about allochthonous origin of clay fraction of studied soils. Clay fraction transported by river waters may be partly derived from morainic soils occurring in the upper river course.

Mineral fraction of soils at Kapuściska and Gleba sites (profiles No. 3, 4, 5) is composed mostly of silt fraction $(51.6 \%-75.0 \%)$, and substantial amounts of clay $(3.1 \%-5.6 \%)$ in comparison to soils at Walery Łeg (profiles No. 1 and 2). The coexistence of humified organic matter and fine-textured mineral matter is termed "mud" in the Polish literature (Okruszko 1969). Higher amounts of clay and silt will determine the evolution of these soils towards black earths (Mollic Gleysols) after drainage. Narrower C:N ratio (8.8-12.0) indicates high mineralization and humification of SOM (the amount of organic carbon is decreased), which is related to the accumulation of soil materials in oxygenated waters and then in conditions of variable moisture.

The mineralogical composition of clay components from the floodplains of Rozoga (Fig. 2-6) and Omulew (Fig. 7 and 8 ) rivers show some similarities. The identified minerals were smectite and vermiculite (there might be also swelling chlorite and/or hydroxyinterlayer vermiculites) as well as certain mixed-layer minerals. The clay components of the studied soils at Walery Łęg in Rozoga river valley (Fig. 2-4) originated from the riverine sediments as they contained more smectite minerals than other soils studied.

Similarly to the investigated alluvial sediments, occurring as an admixture in organic and mineralorganic formation, smectite minerals and swelling minerals prevailed in Fluvisols of Vistula river valley in Poland (Dąbkowska-Naskręt and Dlugosz 1996). The floodplains of other parts of the world had similar mineral composition (Abe et al. 2006;
Nguyen et al. 2006). Clay fractions in soils located in floodplains are subjected to transformations associated with floods and fluctuations of groundwater level (Urushadze et al. 2006).

\section{CONCLUSIONS}

The following conclusions can be drawn from the obtained results:

1. The studied floodplain soils are rich in organic matter and contain considerable amounts of alluvial mineral fraction.

2 . The amount of clay is not high $(3-6 \%$ in the investigated muds) but substantially affects the soil properties and direct evolution of soils after drainage.

3. Studied soils had sandy, loamy sandy and silty loamy textures.

4. Studied soils contained more terrygenic than biogenic silica.

5. Mineral components of studied soils are mostly of allochthonous origin.

6 . The major clay minerals identified in the investigated soils are smectite, vermiculite, illite and kaolinite.

\section{ACKNOWLEDGMENTS}

This research was supported by the Ministry of Science and Higher Education, Poland, grants No. ZP04G03830 and NN 305157639 and research project of University of Warmia and Mazury in Olsztyn No. 20.610.007-300.

\section{REFERENCES}

Abe S.S., Masunaga T., Yamamoto S., Honna T., Wakatsuki T., 2006. Comprehensive assessment on the clay mineralogical composition of lowland soils in West Africa. Soil Science \& Plant Nutrition 52: 479-488.

Bałuk A., 1993. Objaśnienia do szczegółowej mapy geologicznej Polski 1:50 000. Arkusz Ostrołęka (333) (Explanations to detailed geological map of Poland 1:50 000. Sheet Ostrołęka (333)). PIG, Warszawa.

Bengtsson L., Enell M., 1986. Chemical analysis. [In:] Handbook of Holocene palaeoecology and palaeohydrology (Berglund B.E., Ed.) John Wiley and Sons Ltd., Chichester: 423-451.

Borówka R.K., 2007. Geochemiczne badania osadów jeziornych strefy umiarkowanej (Geochemical studies of lake deposits in temperate zone). Studia Limnologica et Telmatologica 1(1): 33-42.

Cieśla W., 1976. Metody przygotowania próbek i separacji frakcji ilastej (Methods of soil preparation and clay fraction separation). Prace Komisji Naukowych Polskiego Towarzystwa Gleboznawczego, VII/2. 
Dąbkowska-Naskręt H., Dlugosz J., 1996. Occurrence and characteristics of layer silicates in alluvial soils from the Lower Wisla river valley, Poland. Applied Clay Science 11(1): $77-83$.

Devesa-Rey R., Barral M.T., 2012. Allochthonous versus autochthonous naturally occurring organic matter in the Anllóns river bed sediments (Spain). Environmental Earth Sciences 66: 773-782.

Gałka M., Kalisz B., 2008. Szczątki roślin kopalnych w glebach mułowych sandru mazursko-kurpiowskiego (Plant macrofossils in mud soils of mazursko-kurpiowski outwash plain). Roczniki Gleboznawcze - Soil Science Annual (3/4): 51-61.

Glina B., Gajewski P., Kaczmarek Z., Owczarzak W., Rybczyński P., 2016. Current state of peatland soils as an effect of long-term drainage - preliminary results of peatland ecosystems investigation in the Grójecka Valley (central Poland). Soil Science Annual 67(1): 3-9.

Goldman C.R., Horne A.J., 1983. Limnology. McGraw-Hill Book Co., New York: 464 pp.

Gonzáles E., Cabezas A., Corenblit D., Steiger J., 2014. Autochthonous versus allochthonous organic matter in recent soil C accumulation along a floodplain biogeomorphic gradient: an exploratory study. Journal of Environmental Geography 7(1/2): 29-38.

Graf-Rosenfellner M., Cierjacks A., Kleinschmit B., Lang F., 2016. Soil formation and its implications for stabilization of soil organic matter in the riparian zone. Catena 139: 9-18.

Heller C., Zeitz J., 2012. Stability of soil organic matter in two northeastern German fen soils: the influence of site and soil development. Journal of Soils and Sediments 12: 1231-1240.

ISO 13317-2. 2001. Determination of particle size distribution by gravitational liquid sedimentation methods - Part 2: Fixed pipette method.

ISO 14235. 1998. Soil quality - Determination of organic carbon by sulfochromic oxidation.

IUSS Working Group WRB, 2015. World reference base for soil resources 2014. International soil classification system for naming soils and creating legends for soil maps. Update 2015. World Soil Resources Report 106, Food and Agriculture Organization of the United Nations, Rome: 188 pp.

Kabała C., Świtoniak M., Charzyński P., 2016. Correlation between the Polish Soil Classification (2011) and international soil classification system World Reference Base for Soil Resources (2015). Soil Science Annual 67(2): 88-100.

Kalembasa D., Pakuła K., Becher M., Jaremko D., 2009. Trace elements in the peat-muck soils in the upper Liwiec river valley. Fresenius Environmental Bulletin 18: 1201-1204.

Kalisz B., Łachacz A., 2008. Morfologia i systematyka gleb mułowych w dolinie Omulwi i Rozogi na Równinie Kurpiowskiej (Morphology and classification of mud soils in Omulew and Rozoga rivers valleys in Kurpie Plain). Roczniki Gleboznawcze - Soil Science Annual 59(3/4): 89-96 (in Polish with English abstract).

Kalisz B., Łachacz A., 2009. Content of nutrients, heavy metals and exchangeable cations in riverine organic soils. Polish Journal of Soil Science 42(1): 43-52.

Kalisz B., Łachacz A., Glazewski R., 2010. Transformation of some organic matter components in organic soils exposed to drainage. Turkish Journal of Agriculture and Forestry 34: 245256.
Kittel P., Płóciennik M., Borówka R., Okupny D., Pawłowski D., Peyron O., Stachowicz-Rybka R., Obremska M., Cywa K., 2016. Early Holocene hydrology and environments of the Ner River (Poland). Quaternary Research 85: 187-203.

Kondracki J., 1972. Pojezierze Mazurskie (Mazurian Lakeland). [In:] Geomorfologia Polski (Geomorphology of Poland) (Galon R., Editor). PWN, Warszawa.

Kondracki J., 2002. Geografia regionalna Polski (Regional geography of Poland). Wydawnictwo Naukowe PWN, Warszawa: $441 \mathrm{pp}$.

Lerman A., Imboden D., Gat J., (Eds). 1995. Physics and chemistry of lakes. Springer-Verlag, Berlin: 334 pp.

Listkowska H., 1999a. Objaśnienia do szczegółowej mapy geologicznej Polski 1:50 000. Arkusz Zręby (292) (Explanations to detailed geological map of Poland 1:50 000. Sheet Zaręby (292)). PIG, Warszawa.

Listkowska H., 1999b. Objaśnienia do szczegółowej mapy geologicznej Polski 1:50 000. Arkusz Kadzidło (293) (Explanations to detailed geological map of Poland 1:50 000. Sheet Kadzidło (293)). PIG, Warszawa.

Łabaz B., Kabała C., 2016. Human-induced development of mollic and umbric horizons in drained and farmed swampy alluvial soils. Catena 139: 117-126.

Łachacz A., Kalisz B., 2016. Polish contribution to the study of moorsh-forming process. [In:] Polish National Committee of International Peatland Society - history, activity, achievements (Łachacz A., Kalisz B., Editors). Wydawnictwo Uniwersytetu Warmińsko-Mazurskiego w Olsztynie, Olsztyn: 115-130.

Mendyk Ł., Świtoniak M., Bednarek R., Falkowski A., 2015. Genesis and classification of the soils developed from the sediments of the farmer Oleszek mill pond basin (the Chetmińskie Lakeland, N Poland). Soil Science Annual 66(1): 29-35.

Nguyen Q.H., Egashira K., Than A.A., Hayashi S., 2006. Clay mineralogical composition of some soils in Myanmar. Clay Science 13(3): 93-100.

Okruszko H., 1969. Powstawanie mułów i gleb mułowych (Development of muds and mud soils). Roczniki Gleboznawcze - Soil Science Annual 20(1): 25-49.

Okruszko H., Ilnicki P., 2003. The moorsh horizons as quality indicators of reclaimed organic soils. [In:] Organic soils and peat materials for sustainable agriculture (Parent L-E., Ilnicki P., Editors). CRC Press, Boca Raton: 1-14.

Oyama M., Takehara H., 1992. Revised Standard Soil Color Charts. Fujihara Industry Co., Tokio.

Piaścik H., Łachacz A., 2001. The effects of the muck-forming process on the sorptive properties of peat soils. Polish Journal of Soil Science 34(2): 69-76.

Polish Soil Classification (Systematyka Gleb Polski), 2011. Roczniki Gleboznawcze - Soil Science Annual 62(3): 1-193 (in Polish with English summary).

Polskie Towarzystwo Gleboznawcze (PTG), 2009. Klasyfikacja uziarnienia gleb i utworów mineralnych - PTG 2008 (Particle size distribution and textural classes of soils and mineral materials - classification of Polish Society of Soil Science 2008). Roczniki Gleboznawcze - Soil Science Annual 60(2): $5-16$.

Pons L.J., 1960. Soil genesis and classification of reclaimed peat soils in connection with initial soil formation. 7th. International Congress of Soil Science 4: 205-211.

Roj-Rojewski S., 2003. Właściwości chemiczne gleb mułowych wykształconych w dolinach zalewowych Narwi i Biebrzy 
(Chemical properties of mud soils formed in the Narew and the Biebrza flood valleys). Acta Agrophysica 87(2): 287-293.

Roj-Rojewski S., 2009. Gleby mułowate - nie wyróżniane dotychczas ogniwo w sekwencji gleb na mułowiskach (Muddy-like soils - the undistinguished link in the sequence of soils in mud habitats). Roczniki Gleboznawcze - Soil Science Annual 60(4): 79-84.

Soil Survey Division Staff, 1993. Soil survey manual. Soil Conservation Service. USDA Handbook No. 18, US Government Printing Office, Washington DC.

Sowiński P., Glińska-Lewczuk K., Kalisz B., Astel A., 2016. Distribution of heavy metals in soils in a postglacial river valley - a geochemical landscape approach. Environmental Engineering and Management Journal 15(6): 1323-1335.

Tobolski K., 2000. Przewodnik do oznaczania torfów i osadów jeziornych (Guidebook for peats and lake deposits determination). Wydawnictwo Naukowe PWN, Warszawa: 508 pp.
Tsheboeng G., Bonyongo M., Murray-Hudson M., 2014. Flood variation and soil nutrient content in floodplain vegetation communities in the Okavango Delta. South African Journal of Science 110(3/4): 64-68.

Urushadze A.T., Chizhikova N.P., Urushadze T.F., 2006. Mineralogical composition of the clay fraction in alluvial soils of eastern Georgia. Eurasian Soil Science 39(5): 516-527.

van Reeuwijk L.P., (Ed). 2002: Procedures for soil analysis. Technical Paper 9. ISRIC, FAO, Wageningen: $120 \mathrm{pp}$.

Wójcicki K.J., 2015. Authigenic and allogenic organic remains as an indicator of geomorphological process activity within the floodplain environment: two case studies from Racibórz Basin, southern Poland. Bulletin of Geography. Physical Geography Series 8: 81-93.

Received: December 8, 2016

Accepted: September 26, 2018

Associated editor: E. Uzarowicz

\section{Skład masy mineralnej odwodnionych gleb $w$ dolinach rzecznych północno-wschodniej Polski}

Streszczenie: Badano gleby w dolinach rzek Rozoga i Omulew w północno-wschodniej Polsce. Badane doliny położone są na równinie sandrowej uformowanej podczas zlodowacenia wisły (Vistulian). Badane gleby są odwodnione, użytkowane jako łąki i zaklasyfikowane do Fluvic Umbric Gleysol, Fluvic Mollic Gleysol, and Eutric Fluvic Histic Gleysol (IUSS Working Group WRB 2015). Celem badań było określenie składu masy mineralnej, a zwłaszcza składu frakcji ilastej, w tym określenie typów minerałów ilastych i ich stadiów przejściowych metodą dyfraktometrii rentgenowskiej (XRD). Gleby występujące na równinie zalewowej są zasobne w materię organiczną i zawierają znaczne ilości $(48,5-89,2 \%)$ aluwialnej frakcji mineralnej. Zawartość frakcji ilastej $(\varnothing<2,0 \mu \mathrm{m})$ jest mała i stanowi od $0,02 \%$ do 5,61\% ogólnej masy mineralnej. Większa zawartość frakcji ilastej dotyczy gleb o większej zawartość materii organicznej, co może świadczyć o łącznej akumulacji obu tych komponentów. W głębszych obniżeniach występujących w dolinach rzecznych (starorzeczach) akumulował się specyficzny utwór określany jako pyłowy muł telmatyczny (16-24\% TOC, 50-75\% frakcji pyłu, 3,1-5,6\% frakcji iłu). Natomiast w płytszych zagłębieniach akumulował się utwór mułowaty $(5,7-7,7 \%$ TOC, piaszczyste uziarnienie). Główne zidentyfikowane minerały ilaste to: smektyt, wermikulit, illit i kaolinit. Skład frakcji ilastej badanych gleb wykazuje podobieństwo do typowych gleb mineralnych występujących w dolinach rzecznych (mady, Fluvisols). Mineralny komponent badanych gleb jest głównie pochodzenia allochtonicznego.

Słowa kluczowe: doliny rzeczne, pyłowy muł telmatyczny, gleby mułowe, minerały ilaste, proces murszotwórczy 